\title{
Työssä oppimisen ja työorganisaatioiden kehittämisen haasteista
}

\author{
KATITIKKAMÄKI
}

Jälkiteollinen aikakausi on tuonut lukuisia työelämää ja organisaatioita koskettavia muutoksia. Muutoksia ovat synnyttäneet mm. informaatio- ja kommunikaatioteknologian nopea kehitysvauhti sekä sen integroituminen osaksi lähes kaikkia elämänalueita. Tekniikan yleistymisen myötä monien ammattien taitovaatimukset ovat muuttuneet ja joissakin töissä jopa kaventuneet. Osa ammateista on poistunut kokonaan ja inhimillinen työvoima on korvattu uutta tekniikkaa hyödyntämällä (Casey 1999, 23).

Organisaatiorakenteiden uudistaminen sekä globaalin maailmatalouden vaikutukset ovat myös merkittäviä muutosten synnyttäjiä. Globalisaation vaikutukset näkyvät eri elämänalueilla ja työelämässä laajasti. Ammattien ja työmarkkinoiden rakenteet ovat muuttuneet, yhteiskunnalliset markkina- ja talousalueet ovat kansainvälistyneet ja koulutettu työvoima liikkuu aktiivisemmin. Demografiset ja sosiaaliset tekijät, kuten eri-ikäisten ja eri elämänvaiheissa olevien työntekijöiden huomioonottaminen, ovat myös synnyttäneet uusia haasteita työelämässä. (Jones 2004, 303-304; Jarvis, Holford \& Griffin 1998, 16-17.)

\section{Verkostoyhteiskunta, kapitalismin uusi kehitysvaihe?}

Nykypäivän yhteiskuntia on luonnehdittu oppimis- ja verkostoyhteiskunniksi. Tiedon tuottaminen ja oppiminen näyttäytyvät globaalissa markkinataloudessa organisaatioiden menestyksen elinehtoina. Castellsin (2000) mukaan verkostoyhteiskunnassa on kyse kapitalismin laadullisesti uudesta kehitysvaiheesta, eli markkinatalouden ja teollisen tuotannon uudelleenorganisoitumisesta. Verkostoituminen ilmenee sekä teknisenä, taloudellisena, organisatorisena että kulttuurisena muutoksena. (Castells 2000, 500-509.) Verkostoyhteiskunnan nähdään nojaavan osaamiseen, minkä yhteydessä puhutaan myös sosiaalisen pääoman keskeisestä merkityksestä. Verkostomaisten organisaatioiden työkulttuuria onkin kuvattu luottamuksen ja asiantuntijuuden kulttuuriksi, jolloin ammattitaitovaatimuksina korostuvat valmiudet yhteistoimintaan, itsenäiseen päätöksentekoon ja toiminnan jatkuvaan kehittämiseen (Helakorpi 2005, 1). Verkostojen korvatessa hierarkkiset rakenteet oppiminen määrittyy verkostoissa tapahtuvaksi aktiiviseksi osallistumiseksi. Oppimisesta, tiedon luomisesta ja innovaatiosta on muodostunut työn ja organisaatioiden kehittämisen keskeisiä alueita. Zuboffin (1990) tapaan oppimisesta voidaan tulkita muodostuneen työelämässä, ainakin retorisella tasolla, tuottavan toiminnan sydän eli jopa uusi työn muoto (Zuboff 1990, 395).

Edellä kuvatut globaalit ja yhteiskunnalliset muutokset sekä koulutuksen muuttuminen eri tilanteissa ja elämänvaiheissa toteutuvaksi oppimiseksi ovat luoneet uusia haasteita myös kasvatuksen ammattilaisille. Elinikäisen oppimisen käsitteen vakiinnuttua osaksi eri alojen asiantuntijoiden puhetta nähdään oppimisen ja kouluttautumisen ulottuvan koko elämänkaaren mittaiseksi ja kaikkia kansalaisia koskevaksi prosessiksi. (Usher, Bryant \& Johnston 1997, 2.) "Yhden totuuden" -ajattelutavan muututtua "vain yhden mahdollisen diskurssin" -ajattelutavaksi painopiste on siirtyi oppijakeskeiseen sekä asioiden tulkitsemista ja reflektoimista painottavaan oppimiskäsitykseen. Samalla huomio on kiinnittynyt painokkaammin informaalin oppimisen ja työssä oppimisen haasteellisiin kysymyksiin. (Jarvis ym. 1998, 2-9.)

Oppimista on tarkasteltu osana työorganisaatiokontekstia itse asiassa jo 1950-luvulta lähtien, kuitenkin lähinnä hallinto- ja liiketaloustieteiden näkökulmasta sekä innovoinnin ja johtajuuden teemoihin painottuen (March \& Simon 1958; Drucker 1985; Hamel \& Prahalad 1994). Oppiva 
organisaatio -käsite yleistyi 1980-90 -lukujen vaihteessa korostamaan organisaatioiden oppimista tukevia arvoja, rakenteita ja prosesseja sekä toisaalta oppivia yksilöitä (mm. Senge 1990). Kyseistä lähestymistapaa on kuitenkin kritisoitu muun muassa sen painottumisesta yksilöllisiin ajatteluprosesseihin sekä tiedon korostamisesta (Nicholini, Gherardi \& Yanow 2003).

\section{Työssä oppimisen käsitteen ja tutkimuksen ulottuvuuksia}

Työssä oppimisen käsite ja tutkimus yleistyivät puolestaan vasta 1990-luvun loppupuolella. Työelämän muutoksen tarkastelu ja ohjaaminen sekä työssä oppimiseen ja työorganisaatioiden kehittämiseen liittyvät kysymykset askarruttavat nykyisin monien eri tieteenalojen, joskin toisiaan lähellä olevien tutkimusalojen edustajia. Aiheesta on kirjoitettu kasvatustieteiden lisäksi mm. sekä johtamisen ja liiketalouden, organisaatiotutkimuksen, psykologian sekä työn sosiologian näkökulmista. Suomen lisäksi työssä oppimisen alueen tutkimusta tehdään aktiivisesti esimerkiksi Australiassa, Englannissa, Kanadassa, Ruotsissa ja Tanskassa.

Työssä oppimisen tarkastelu on laajentunut yksilö-, ryhmä- ja organisaatiokonteksteihin. Oppimista ja työprosesseja tarkastellaan myös samanaikaisesti, ja tämän lisäksi oppimisen tarkastelussa korostuu sen kontekstisidonnainen ja informaali luonne. Käsitteen erilaiset ymmärrystavat kuitenkin vaihtelevat puhujan tai kirjoittajan ideologisesta lähtökohdasta riippuen. Kirjoituksista on tulkittavissa intressejä aina organisaatioiden tehokkuuden ja tuottavuuden edistämisestä yksilöiden ja sosiaalisten yhteisöjen tietojen ja taitojen kehittämiseen sekä ammatillisen sivistyksen edistämiseen.

Vaikka oppimista koskeva julkinen keskustelu on ollut vilkasta, on toistaiseksi kuitenkin ollut löydettävissä hyvin vähän tutkittua ja kriittistä tietoa työssä oppimisen luonteesta, ehdoista, edellytyksistä ja merkityksestä niin työntekijöiden kuin organisaatioidenkin kannalta. Etenkin väitöskirjassani käsiteltäviä ammatteja, kuten myyntityötä ja saattohoitoa, on tutkittu työssä oppimisen näkökulmasta ainakin toistaiseksi varsin vähän.

Työn organisoinnilla on keskeinen merkitys työssä oppimisessa. Tarkasteltaessa työn organisoinnin kehitystä oppimisteorioiden näkökulmas- ta onkin havaittavissa mielenkiintoisia samankaltaisuuksia. 1980-luvulta lähtien työn organisoinnin prosessit ja ideat oppimisen luonteesta ovat lähentyneet selvästi toisiaan. Oppiminen on työtä, mutta vastaavasti työ on muuttunut jatkuvaksi uuden oppimiseksi. Useiden nykypäivän oppimisteorioiden valossa oppija nähdään aktiivisena ja tietoa konstruoivana yksilönä, jonka toiminnassa reflektiolla ja sosiaalisella vuorovaikutuksella on merkittävä osuus. Vastaavasti työntekijän roolin on nähty muuttuvan työn suorittajasta monimuotoista asiantuntijuutta omaavaksi sekä itseään ja työtään jatkuvasti kehittäväksi asiantuntijaksi. Sosiaalisten vuorovaikutus- ja kommunikointitaitojen merkitys on kasvanut ryhmä-, tiimi- ja projektiluonteisten työmuotojen yleistyttyä. Nykypäivänä monien alojen työntekijät nähdään aktiivisina, sosiaalisina ja uutta tietämystä omaksuvina elinikäisinä oppijoina, joiden odotetaan sopeutuvan työelämässä tapahtuviin jatkuviin ja nopeisiin muutoksiin. (Heikkilä \& Tikkamäki 2005, 80-81.)

Nykyisin on kuitenkin tunnistettavissa varsin ristiriitaisia työn organisoinnin ja kehityskulun muotoja. Haastavien, työntekijöiden oppimismahdollisuuksia peräänkuuluttavien ja monipuolista osaamista vaativien töiden lisäksi ovat kasvussa rutiiniluontoiset ja pienipalkkaiset palvelusektorin työt kuten vartiointi, siivous sekä avustavat hoitotyöt. Tämäntyyppisissä töissä osaamisalueina korostuvat muun muassa laajat sosiaaliset taidot. Osassa palvelualan organisaatioita on saanut jalansijaa macdonalsoitumiseksi kutsuttu ilmiö, jossa työn organisointi palaa lähelle taylorismin periaatteita. Työn tehokkuus ja nopeatempoisuus ovat johtaneet ositettuun ja monotoniseen työn organisointiin sekä työntekijöiden kontrollointiin. Työn suunnittelu ja toteuttaminen on erotettu toisistaan, jolloin työssä oppimisen ja kehittymisen mahdollisuudet ovat kaventuneet. (Ritzer 1996.)

\section{Työkiire este työssä oppimiselle}

Tutkimusten mukaan myös kiireestä on tullut viimeisten 10-15 vuoden aikana työelämää haitallisesti leimaava piirre (Järnefelt \& Lehto 2002). Kiireen on todettu lisääntyneen selvästi etenkin juuri myyntityötä, kaupallista työtä ja palvelutyötä tekevillä naisilla. Aikapaineet, työn pakkotahtisuus ja huonot työaikajärjestelyt ovat paljastuneet eniten työssä viihtymistä haittaaviksi sekä työuupu- 
musta aiheuttaviksi tekijöiksi (Kalimo \& Toppinen 1997, 7). Tämänkaltaiset tulokset johtavat kysymään, millainen rooli oppimisella tämän päivän kiireisessä työelämässä on, sekä mitä kiireisessä työn arjessa lopulta ehditään oppimaan? Organisaatioiden ja töiden organisoinnin ensisijaisena tavoitteena on aina ollut tuottavuuden ja tehokkuuden maksimointi, joihin humanistiset työn suunnittelun periaatteet on pyritty yhdistämään (Vartiainen 1994).

\section{Hiljainen tieto on hedelmällinen pohja uuden oppimiselle}

Informaalin oppimisajattelun yleistymisen myötä työpaikat on tunnistettu relevanteiksi oppimisympäristöiksi ja huomio on laajentunut henkilöstökoulutuksen ulkopuolisiin oppimismahdollisuuksiin. Watkinsin ja Marsickin (1992) klassisen määritelmän mukaan informaali oppiminen on oppimista kokemuksista, joka tapahtuu juuri formaalisti organisoitujen ja institutionaalisten toimintojen ulkopuolella. Informaali oppiminen voi olla joko suunniteltua tai suunnittelematonta. Se sisältää kuitenkin aina myös ennalta arvaamattoman satunnaisoppimisen, jolloin hiljainen tieto luo hedelmällisen pohjan oppimiselle. Ammattitaidon kehittämisen ja uuden oppimisen ajatellaan mahdollistuvan päivittäisessä työssä. Ongelmat ja opittavat asiat tulevat eteen työtä tehtäessä ja edellyttävät välitöntä ratkaisua. Työntekijän aikaisemmat kokemukset ja niiden pohjalta tapahtuva tilanteissa reagointi ovat siis merkittäviä. Jos opittu jää tiedostamattomalle ja jakamattomalle tasolle, se voi lisätä virheiden mahdollisuutta. Ihmisten tulisikin jatkuvasti testata uskomuksiaan, eikä toimia pelkkien olettamustensa pohjalta. (Watkins \& Marsick 1992, 293-298.)

Kokemusten tiedostaminen, olettamusten aukipurkaminen ja toimintatapojen perusteleminen mahdollistuvat reflektiivisen toiminnan avulla. Reflektion merkitys on tunnistettu perinteisen kouluoppimisen, organisoidun sekä kokemuksellisen oppimisen alueilla jo 1980-luvulta lähtien, mutta reflektiivisten prosessien kytkeminen tiiviisti työkontekstissa toteutuviin toimintoihin on suhteellisen uusi ajattelutapa. Työssä oppimisen kannalta keskeinen kysymys on kuitenkin juuri se, missä määrin ja minkä luonteisia reflektiivisiä prosesseja työ- ja organisaatiokonteksteissa on tai niihin luodaan.

Reflektion luonteesta, sen osuudesta toimin- nassa sekä sen ilmenemismuodoista on olemassa useita erilaisia tulkintoja. Yleisimmin reflektiolla on viitattu yksilön kognitiivisiin prosesseihin kuten muun muassa tiedostamiseen, analysoimiseen, kyseenalaistamiseen sekä vaihtoehtoisten ajattelutai toimintatapojen etsimiseen (Mezirow 1981; Schön 1983; Marsick 1995). Cresseyn, Boudin \& Dochertyn (2006) tuoreen julkaisun mukaan yksilön kouluttamisesta ja oppiva organisaatio ajattelusta on edetty tuottavan reflektion eli productive reflection -aikaan. Tuottavan reflektion -käsite korostaa työkontekstissa toteutuvan reflektion kollektiivista luonnetta. Käsitteen lanseeranneet tutkijat tarkoittavat tuottavalla reflektiolla prosesseja, jotka edistävät joustavissa projektiryhmissä tapahtuvaa jaettua asiantuntijuutta, monitorointia ja interventioita, joissa ongelmanratkaisu ja muutos ovat keskeisessä roolissa. Tuottava reflektio -käsite assosioituu herkästi organisaation tavoitteiden ja tehokkuuden palvelemiseen. Kirjoittajat kuitenkin korostavat ajattelevan ja aktiivisen subjektin keskeistä roolia työkäytännöissä sekä työntekijöiden henkilökohtaisen elämänlaadun priorisoimisen tarvetta pitkäjänteisen toiminnan saavuttamiseksi. Haasteeksi muodostuu reflektion tarkasteleminen luontevana osana työprosesseja sekä sen legitimoiminen osaksi arkista työtä.

\section{Työssä oppiminen heijastuu monessa ja monin tavoin}

Työssä oppimisella on tavoiteltu työntekijöiden vaikutusmahdollisuuksien lisäämistä, esimerkiksi osallistamalla työntekijöitä tuotantoprosessien ja organisaatioiden kehittämiseen. Työssä oppimiseen on liitetty pääasiassa positiivisia konnotaatioita ja siitä on nähty olevan hyötyä sekä työntekijöille että työnantajille. Työn humanisoinnin on uskottu parhaimmillaan lisäävän työntekijöiden oppimisen mahdollisuuksia sekä työn mielekkyyttä. Työssä oppimisen arvostuksen nousun ja sen edellytysten paranemisen on nähty parhaimmillaan vaikuttavan positiivisesti myös henkilöstön työssä jaksamiseen sekä laajemmin työyhteisön hyvinvointiin.

Työssä oppimiseen liittyy kuitenkin myös useita kriittisiä kysymyksiä. Työssä oppimista tuleekin aina tarkastella suhteessa kontekstiinsa. Vaarana monissa töissä on se, että oppiminen kapeutuu rutiiniluontoiseksi sopeutumiseksi ja tuottavuuden tehostajaksi viitaten muun muassa paljon 
puhuttuun työelämää häiritsevään kiireeseen. Garrickia (1999) lainaten, informaalin oppimisen taustalta voi olla löydettävissä organisaatioiden tehokkuutta palveleva piilo-opetussuunnitelma. Työssä oppimisen ja jatkuvan kehittämisen retoriikkaa voidaan käyttää keinona maksimoida organisaation tehokkuutta, painostamalla työntekijöitä jatkuvaan uudistumiseen organisaation tulostavoitteiden nimissä. Voitaisiinko oppimisella ja reflektiolla kuitenkin nähdä työkontekstissa itseisarvo sinänsä?

Työssä oppimisen ilmiö on hyvin laaja ja moniselitteinen, sekä ristiriitainen ja jännitteinen. Sen tarkastelussa kohtaavat väistämättä oppimiseen ja kehittymiseen tähtäävät humaanit arvot sekä yritys- ja organisaatiomaailman tehokkuusajattelu. Uudistuksissa ja työlle asetettavissa tavoitteissa saattavat usein olla vastakkain organisaation ja työntekijöiden tarpeet. Yritys pyrkii mahdollisimman hyvään tuottavuuteen ja yksilö puolestaan sopeuttamaan työn omiin tarpeisiinsa sekä elämänkokonaisuuteensa. Epäreiluksi asetelman tekee se, että samanaikaisesti kun työntekijöiltä edellytetään suurempaa vastuuta sekä sitoutumista itsensä ja työnsä kehittämiseen, on monilla työnantajilla tarjota vastapalvelukseksi lyhyitä työsuhteita ja epävarmuutta tulevaisuudesta. (Shied, Howell, Carter \& Preston 1998, 285-288.)

Vallan, asiantuntijuuden sekä oppimisen käsitteiden voidaan ajatella olevan erottamattomia. Valtasuhteet vaikuttavat väistämättä siihen, mitä ja miten työssä opitaan, millaista sekä kenen ammattitaitoa arvostetaan sekä millainen oppiminen organisaatioissa yleensä ottaen mahdollistetaan (Blackler \& McDonald 2000). Työkontekstiin paikantuvassa oppimisessa on tunnistettavissa useita haasteellisia filosofisia, poliittisia sekä eettisiä kysymyksiä (Garrick 1999).

Työpaikkoja ja organisaatioita voidaan pitää potentiaalisina ja monipuolisina oppimiskonteksteina, mutta keskeinen kysymys on kuitenkin se, millaista oppiminen on luoteeltaan sekä mitä oppimisella kulloinkin tavoitellaan. Keskeistä on se, mitä toimintoja työkontekstissa tunnistetaan ja nimetään oppimiseksi ja reflektioksi, sekä mihin tarkkaavaisuus kulloinkin suunnataan. Voimakkaita muutosprosesseja läpikäyvissä organisaatioissa on vaarana, että jatkuvan uudistumisen ja kehittymisen vaatimus voi kääntyä itseään vastaan. Jatkuvasta uuden oppimisen ja kehittämisen paineesta voi tulla työntekijöille ja organisaatioille lisärasite, mikä koetaan käytännös- sä työmäärän lisääntymisenä sekä jatkuvana ponnisteluna yhä vaativampien tavoitteiden saavuttamiseksi. Uudistusten ja muutosten yhteydessä olisi tärkeää kiinnittää huomiota siihen, kenen ehdoilla joustavuutta ja uudistuksia loppujen lopuksi toteutetaan, sekä mitä työelämässä tapahtuvat muutokset sekä oppimista koskevat vaatimukset merkitsevät eri osapuolten näkökulmasta arvioituna. Työssä oppimisen tarkastelussa on haastavinta huomioida sekä työntekijöiden, työyhteisöjen että työorganisaatioiden tarpeet.

\section{Lähteet}

Blackler, F. \& McDonald, S. (2000). Power, mastery and organizational learning. Journal of Management Studies, Vol. 37, No. 6, 833-851.

Casey, C. (1999). The changing contexts of work. Teoksessa D. Boud, \& J. Garrick (toim.) Understanding learning at work. London: Routledge, 15-28.

Castells, M. (2000). The rice of networksociety. Oxford: Blackwell.

Cressey, P., Boud, D. \& Docherty, P. (2006). The emergence of productive reflection. Teoksessa D.Boud, P.Cressey \& P.Docherty (toim.) Productive reflection at work. Oxon: Routledge.

Drucker, P. (1985). Innovation and enterpreneurship. Englanti: Butterworth-Heinemann.

Garrick, J. (1999). The dominant discourses of learning at work. Teoksessa D. Boud \& J. Garrick (toim.) Understanding learning at work. London: Routledge, 216-231.

Hamel, G. \& Prahalad, C.K. (1994). Competing for the future. Boston (Mass.): Harward Business School Press.

Heikkilä, K. \& Tikkamäki, K. (2005). Työ ja oppiminen kaupan, teollisuuden, uusmedian ja hoiva- alan organisaatioissa. Teoksessa E. Poikela (toim.) Osaaminen ja kokemus. Tampere: Tampere University Press, 77-97.

Helakorpi, S. (2005). Verkostot ja muuttuva asiantuntijuus. Kever, No. 4., 1-9. [www-dokumentti] <http://www.piramk.fi/kever/ kever.nsf $>$, luettu 5.1.2006.

Jarvis, P., Holford, J. \& Griffin, C. (1998). The theory and practise of learning. London: Kogan 
Page Limited.

Jones, G.R. (2004). Organizational theory, design, and change. Texts and cases. USA: Pearson Education.

Järnefelt, N. \& Lehto, A-M. (2002). Työhulluja vai hulluja töitä? Tutkimus kiirekokemuksista työpaikoilla. Helsinki: Tilastokeskus.

Kalimo, R. \& Toppinen, S. (1997). Työuupumus Suomen työikäisellä väestöllä. Helsinki: Työterveyslaitos.

March, J.G. \& Simon, H.A. (1958). Organizations. USA: John Wiley \& Sons, Inc.

Marsick, V.J. (1995). Toimintaoppiminen ja reflektio työpaikalla. Teoksessa J. Mezirow ym. (toim.) Uudistava oppiminen: kriittinen reflektio aikuiskoulutuksessa. Helsinki: Helsingin yliopiston Lahden tutkimus- ja koulutuskeskus, 41-65.

Mezirow, J. (1981). Transformative dimensions of adult learning. San Fransico: Jossey-Bass.

Nicholini, D., Gherardi, S. \& Yanow, D. (2003). Introduction: Toward a practise-based view of knowing and learning in organizations. Teoksessa D. Nicolini, S. Gherardi \& D. Yanow (toim.) Knowing in Organizations. A Practice-Based Approach. New York: Sharpe, cop., 3-31.

Ritzer,G. (1996). McDonaldization of society: an investigation into the changing character of contemporary social life. California: Pine Forge Press.

Schön D.A. (1983). The reflective practitioner. How professionals think in action. New York: Basic Books.

Shied, F.M., Howell, S.L., Carter, V.K. \& Preston J.A. (1998). Creating contingency workers: A critical study of the learning organization.

Usher, R., Bryant, I. \& Johnston, R. (1997). Adult education and the postmodern challenge. Learning beyond the limits. London: Routledge.

Vartiainen, M. (1994). Työn muutoksen työvälineet: Muutoksen hallinnan sosiotekniset menetelmät. Espoo: Otatieto.

Watkins, K.E. \& Marsick, V.J. (1992). Towards a theory of informal and incidental learning in organizations. International journal of lifelong education. Vol. 11., No. 4., 287-300.

Zuboff, S. (1990). Viisaan koneen aikakausi. Uusi tietotekniikka ja yritystoiminta. Helsinki: Otava.

Lektio 8.9.2006. KM Kati Tikkamäen väitöstutkimus "Työn ja organisaation muutoksissa oppiminen etnografinen löytöretki työssä oppimiseen" tarkastettiin Tampereen yliopistossa 8. syyskuuta 2006 vastaväittäjänä professori Anneli Eteläpelto Jyväskylän yliopistosta. Väitöskirja on myös sähköisenä sarjassa Acta Electronica Universitatis Tamperensis, http://acta.uta.fi. 